\title{
A bányahivatalnokok jogi helyzete Magyarországon a 18. században
}

\author{
The Legal Position of the Mine Officials in Hungary in the $18^{\text {th }}$ Century
}

\begin{abstract}
ABSZTRAKT
A Habsburg uralkodók központosítási törekvései a bányaigazgatás területén a 18. században felerősödtek. Ezzel el kivánták érni, hogy a bányákból befolyó hasznokról a rendeket kizárva, egyedül tudjanak dönteni. Ehhez szükséges volt a rendektöl elszakitott hivatalnoki kar felállitása, amit a tisztviselökre vonatkozó aprólékos szabályozással tudtak megvalósítani. A hivatalnokok jogi helyzetének bemutatása az abszolutizmus müködésének feltárásához is segítséget nyújt.
\end{abstract}

Kulcsszavak: bányatisztviselök, bányahatóság, Habsburg udvar, központositás, bürokrácia

\begin{abstract}
In the $18^{\text {th }}$ century the centralization efforts of the Habsburg rulers were intensified in the field of mining administration. Their aim was to be able to dispose of mine revenues without the orders. For this purpose, by the circumstantial regulation of the position of the officials, they set up a new official staff which was independent of the orders. By studying the legal position of the officials we can better understand the working mechanism of an absolutist system.
\end{abstract}

Keywords: mine official, mining authority, Habsburg court, centralization, bureaucracy

A bányajog történetének egyik legjelentősebb kutatója, Wenzel Gusztáv, a bányaigazgatásban bekövetkező 18. századi változásokkal kapcsolatban a következőket jegyzi meg:

A magyar bányászatra vonatkozó törvények és rendeleteknek, Schmidt Ferencz Antal által közzétett gyűjteményében Mária Terézia kora nyolcz, (VII-XIV) II. József kora pedig negyedfél (XV-XVIII) kötetet ${ }^{1}$ foglal el. Anélkül, hogy ezeknek részleteibe

\footnotetext{
* Dr. Gedeon Magdolna, egyetemi docens, Miskolci Egyetem ÁJK, Római Jogi Tanszék, e-mail: jogmagdi@ uni-miskolc.hu.

1 ScHMIDT, Franz Anton: Chronologisch Systematische Sammlung der Berggesetze der Österreichischen Monarchie. Wien, J. P. Sollinger, 1832-1839. II. Abteilung: Chronologisch Systematische Sammlung der Berggesetze der Königreiche: Ungarn, Kroatien, Dalmatien, Slavonien und des Grossfürstenthums Siebenbürgen (a továbbiakban ScHMIDT: i. m., kötet/oldalszám), 7-18. kötetek. A Schmidt-féle „okmánytár hármas csoportosításban, összesen 39 kötetben, mintegy 20000 oldalnyi terjedelemben, idörendbe szedve adta közre a bécsi levéltárakban található, bányászatra, kohászatra és erdészetre vonatkozó, és ezen belül is elsősorban e szakterületek kincstári igazgatásával összefüggő, máig kevéssé ismert, és csak részben feldolgozott korabeli törvényeket, rendeleteket, utasitásokat, illetve egyéb okiratokat. A bányajoggal kapcsolatos jogszabályokat időrendben foglalja össze...” Izsó István: A montanisztika magyarországi történetének levéltári
} 
bocsátkoznánk, röviden csak azt jegyzem meg, hogy a bányaigazgatás alsó, vagyis localis és vidéki organumai hivatalos hatalmukból nagyobbára kivetkőztettek, s hogy e hatalom királyi tisztekre lett ruházva. ${ }^{2}$

A bányászati tevékenység Magyarországon az államalapítás óta kiemelt jelentőséggel bírt, hiszen a nemesfémek a pénzérmék alapanyagát képezték. Ennél-fogva Szent Istvántól kezdve az ércbányászatból származó termékek jogi sorsának rendezése az államhatalom rendelkezési jogának megalapozására irányult. A helyzetet azonban bonyolította, hogy a bányászati-kohászati tevékenység nagy szakértelmet és jelentős tőkebefektetést igényelt, amivel az uralkodók nem rendelkeztek. Ez a kényszerüség vezetett az uralkodó és a bányavállalkozók közötti együttműködéshez, és az ezen alapuló szabályozásban fellelhető számos kompromisszumhoz.

A Habsburgok trónra lépésével ez az együttműködés felbomlott. A vonatkozó forrásokból egyértelmúen kiderül, hogy a központosítási törekvések a bányászati tevékenység igazgatásában hamarabb megjelentek, mint más területeken. Így az udvar erőfeszítései, hogy az ebből a gazdasági ágazatból eredő bevételeket az osztrák uralkodók csak a saját igényeik és akaratuk szerint, a rendek beleszólása nélkül tudják felhasználni, már a 16. századtól nyomon követhetők. A központosítási törekvések egyik fő tényezője a bányaigazgatásban egy zárt bürokrácia kiépítése volt, amely az uralkodó kézi vezérlése alatt állt. Ezt Fridrich Walter a Mária Terézia uralkodása alatt végbevitt közigazgatási változtatásokkal kapcsolatosan a következőképpen foglalta össze:

Szükségszerű volt egy alkotmányreform, egy államreform, amely a közigazgatási reformmal járt együtt. A végső, általános cél a rendi hivatalnokok lecserélése az uralkodó embereire. A rendi középső és alsóbb hivatalnoki kar a rendek által védelmezett körfal volt, amely a tartományi vezetőket elszigetelte, és nem engedte az alsóbb beosztottakhoz. Ezt el kellett távolítani, hogy az uralkodói túlsúlyt a jövőre nézve teljes egészében biztosítani lehessen. ${ }^{3}$

A bányaigazgatásban - mint említettük - ezért hamarabb jelentkeztek a központi törekvések, mint a közigazgatás egyéb területein. A montángazdaságból ${ }^{4}$ származó

\footnotetext{
forrásai II. Központi Bányászati Múzeum Alapítvány, Sopron, 2009, 4. A bécsi levéltári kutatásokon alapuló tanulmányok megfelelöen tükrözik, hogy a Schmidt-féle gyüjtemény feleslegessé teszi az eredeti iratok tanulmányozását, hiszen azáltal új, jogilag releváns forrásokat, kutatási eredményeket nem lehet felmutatni. Ezt a megállapítást azok a témával kapcsolatos igen részletes és elismert munkák is alátámasztják, amelyeket alkotójuk kizárólag a gyüjteményben található joganyag alapján írt meg. Lásd például Mihalovits János munkáit.

2 WENZEL Gusztáv: Magyarország bányászatának kritikai története. MTA, Budapest, 1880, 248.

${ }^{3}$ WALTER, Friedrich: Österreichische Verfassungs- und Verwaltungsgeschichte von 1500-1855. Böhlau, WienKöln-Graz, 1972, 94 (fordította: G. M.).

${ }^{4}$ A bányászattal összekapcsolódott a pénzverés, a kohászat és az erdőgazdálkodás is, amelyek együttvéve a montanisztika fogalomkörébe esnek. A pénzverés szabályozása azonban a többi területtől lényegesen eltér, ezért a bányászat-kohászat és a fenntartásukhoz szükséges erdőgazdálkodás igazgatásának és összefüggő szabályozásának bemutatása áll az ezzel a gazdasági ágazattal foglalkozó szakirodalom középpontjában. A rendelkezésre álló forrásokban is ez utóbbi három területre vonatkozó jogi szabályozás képez egy külön csoportot.
} 
bevételeket ugyanis a Habsburg uralkodók a magyar érdekek figyelmen kívül hagyása mellett, háborúik finanszírozásához teljes mértékben meg akarták szerezni. A hivatalokban ezért ezen a területen jelentek meg először azok a hivatalnokok, akikről Ember Győző a következőket írta:

Míg a közigazgatás más ágaiban a hübéri jellegű familiáris szolgálat a középkor örökségeképp a 16. és 17. században is továbbél, a bányatisztviselök szinte kivétel nélkül hivatásos hivatalnokok, akik pályájukra rendszeresen készülnek és azon életük végéig vagy ameddig erejük engedi, megmaradnak, s közben semmi mással nem foglalkoznak. ${ }^{5}$

\section{A hivatalnokok kinevezésére vonatkozó szabályok}

A hierarchikus bürokratikus szervezet kialakítása a montanisztika igazgatásában a hivatalokban dolgozókra vonatkozó előírások megalkotását is szükségessé tette. A hivatalnokok feladatainak leírását a részükre föként az udvari központi szakigazgatási szervek által kiadott instrukciók tartalmazták. Ezek az instrukciók koronként és helyenként is változatos képet mutatnak. A feladatok leírása mellett az utasítások részletezték a hivatalnokokat megillető fizetés összegét, és a nekik járó, természetbeni juttatásokat is. Ezekre nézve számos példát találunk a Schmidt-féle jogszabálygyűjteményben, amelyben az egyes hivatalok felállításakor részletesen szabályozták, melyik hivatalnoknak mennyi lesz a fizetése, hol lakhat, milyen természetbeni juttatásokban részesül, például mennyi fát kap füteni, és faggyút világítani. ${ }^{6} \mathrm{~A}$ személyekhez kötődő, elismerési jelleggel történő kinevezésekre is találunk példát. ${ }^{7}$

A 18. században az állás betöltéséhez alapvető feltételt képezett a katolikus vallás és a tisztességes életvitel. Az egyes hivatalnokoknak adott instrukciók ezekkel a feltételekkel kezdődtek. A Miksa-féle bányarendtartás ${ }^{8}$ azt is előírta, hogy a hivatal-

${ }^{5}$ EMBER Győző: Az újkori magyar közigazgatás története Mohácstól a török kiüzéséig. Irodalmi, Művészeti és Tudományos Intézet, Budapest, 1946, 364.

${ }^{6}$ Ezért téved Ember Győző, amikor azt állítja, hogy a kinevezett tisztségviselők „terményekben csak ritkán” kapták juttatásaikat. EMBER: i. m., 364.

7 Péch Antal a következőkről számol be: „A hivatalok betöltésére nézve egy jellemző eset van feljegyezve ez évből. 1602. augusztus 22-én jóváhagyta az alsóausztriai kamara, hogy mivel Rosenauer Péter néhai aranyválató a hivatalát sok ideig jól viselte, a válatói hivatal az ő fiára, Rosenauer Pálra szálljon, és minthogy ez még kiskorú, helyette Hörl Boldizsár vétessék fel 16 évre a válatói hivatal ellátása végett azon kötelezettséggel, hogy ez idő alatt az épületeket és készülékeket jó karban tartsa, és a fiatal Rosenauert megtanítsa mindenre, a mit ő az öreg Rosenauertól tanult." Ebböl az esetből arra is következtethetünk, hogy a tisztségek betöltésére vonatkozóan a helyi javaslatokat figyelembe vették. Lásd PÉcH Antal: Alsó-Magyarország bányamívelésének története II. MTA, Budapest, 1887, 24.

8 Többszöri átdolgozás után az új bányarendtartás, az ún. „Maximilianische Bergordnung” 1560-ban készült el, és számos próbálkozás után II. Miksa császár hirdette ki 1565. február 10-én (lásd Kundmachungspatent, 1565. február 10. SchmidT: i. m., 2/1. További kiadása: Neue Berg-Ordnung des Königreichs Ungarn, und solcher Cron einverleibten Gold, Silber, Kupfer, und anderer Metall- Bergwerken, Sammt denen Erläuterungen zweyer Alten Berg-Ordnungen Der sieben königl. Freyen Berg-Städte 1. Chemnitz u. Königsberg 2. Schemnitz, Neusohl, Bugganz, Dülln und Libeten. Aus der k. auch k. k. Hof- und Staats Druckerey, Wien, 1805, a továbbiakban MBO). A magyar felfogás szerint a montángazdaságból befolyó jövedelem felhaszná- 
nokok egymással szemben is tisztességet tanúsítsanak (MBO XLIII. 1. §). Egy rendelet pedig általános jelleggel megtiltotta, hogy a bányászati hivatalokra nem katolikus személyt válasszanak. ${ }^{9} \mathrm{~A}$ hivatalnokok vallásgyakorlását pedig azzal is elö kívánták segíteni, hogy csak egy vagy két tisztviselönek kellett vasárnap és a nem parancsolt ünnepnapokon a mise után a hivatalban tartózkodnia, parancsolt ünnepeken azonban a mise után csak tíz órától volt köteles az összes hivatalnok a hivatalban dolgozni. ${ }^{10}$ Ezzel a katolikus Habsburgok tovább kívánták erősíteni a hivatalnokok hozzájuk való hüségét.

Az egyes hivatalokra esetenként személyekre szabott instrukciók mellett általános szabályokat is találunk a forrásokban a tisztségek betöltésére vonatkozóan, amelyekből kiderül, hogy az uralkodó saját maga kívánta a kiválasztásukat ellenőrizni. Az uralkodó 1626 októberében a Bécsben tartózkodó főkamaragrófot ${ }^{11}$ is arra figyelmeztette, hogy a kinevezések minden esetben „a királynak vannak fenntartva”, a javaslatokat ezért mindig hozzá kell felterjeszteni. ${ }^{12}$ Így I. Ferdinánd már 1627-ben királyi leiratban rendelte el, hogy a fökamaragróf sem nevezhet ki hivatalnokot csak ideiglenes jelleggel, és eskütétel nélkül. Az uralkodó maga így ebben a leiratban több tisztviselöt is kinevezett az újonnan felállított kohóüzemekbe. ${ }^{13}$

1652-ben III. Ferdinánd magának akarta a kinevezési jogkört fenntartani, ezért azt is megtiltotta, hogy a királyi biztos vagy a fötisztek akár a legalacsonyabb tisztségek vonatkozásában gyakorolják a kinevezést. ${ }^{14}$ Majd az Udvari Kamara elöírta, hogy még a fökamaragróf is köteles a kamarai kinevezéseket először a király elé terjeszteni. A dekrétum megszövegezéséből kiderül, hogy a király egyetértésére

lásáról az uralkodó nem dönthetett egyedül, a bányák a Szent Korona bevételeit gyarapították, ezért ezekröl a hasznokról az uralkodónak elvileg mindig ki kellett volna kérnie a rendek véleményét. Az új bányarendtartás azt az idegen - a nyugati hübériség alapján megfogalmazott - elvet akarta az országba bevezetni, amely szerint az uralkodó a bányaregáléval kapcsolatos ügyekben önállóan, mindenki mást kizárva intézkedhetett. 1723-ban a CVIII. törvénycikkben, a bányarendtartást mint a bányabíróságokon használatos lex privatát, törvényként ismerték el („,1723. évi CVIII. törvénycikk a bányai bíróságoknak az ország törvényeihez idomításáról. A bányabíróságok, azoknak több mint egy század elött megállapított magán-törvényei szerint, mostani állapotukban fognak maradni." Lásd Márkus Dezső [szerk.]: Corpus Juris Hungarici III, Franklin, Budapest, 1900, 647, a továbbiakban CJH). A Miksa-féle bányarendtartás kihirdetésétől a szakirodalom egybehangzó megállapítása szerint új szakaszba lépett a magyarországi bányajog fejlődése. Ezzel ugyanis a magyar bányajog belső fejődése megakadt, azt a Habsburg uralkodók a saját felfogásuknak megfelelően, saját anyagi érdekeik szerint alakították.

${ }^{9}$ Az Udvari Kamara dekrétuma, 1631. szeptember 20. ScHMIDT: i. m., 4/582. Péch Antal beszámolója szerint 1601-ben a selmeci pénztárnoki állásra Vischer Erasmust nevezte ki az uralkodó. Bár a tisztviselőt Rudolf nevezte ki, a kinevezés Mátyás föherceg ajánlatára történt, aki nem vette figyelembe, hogy Vischer Erasmus lutheránus volt. Mikor rájöttek a hibára, Rudolf azt írta Mátyás föhercegnek, hogy Vischer Erasmust mondassák le, hiszen kinevezése nem az Udvari Kamara hozzájárulásával történt, sőt az országból is utasítsák ki lutheránus pap testvérével együtt. A pénztárnoki állást pedig egy katolikus személlyel kell betölteni. Bár a tisztviselő megbízható, jó munkaerő volt, két év után mégis elbocsátották. Lásd PÉcH (1887): i. m., 14-17.

${ }^{10}$ Az Udvari Kamara dekrétuma, 1766. december 17. SchMIDT: i. m., 12/473.

${ }^{11}$ A fökamaragróf alapvetően az alsó-magyarországi bányaigazgatás vezetésére rendelt, az uralkodó akaratát képviselő hivatalnok volt. A 18. század folyamán ez a tisztség egy kollegiális szervvé - a Főkamaragrófi Hivatallá, élén a fökamaragróffal - alakult át, amelynek illetékessége az ország összes bányakerületére kiterjedt.

12 Királyi leirat, 1626. október 16. ScHMIDT: i. m., 4/457; PÉCH (1887): i. m., 210.

${ }^{13}$ Királyi leirat, 1627. augusztus 13. SCHMIDT: i. m., 4/459; PÉCH (1887): i. m., 233; EMBER: i. m., 364.

${ }^{14}$ Királyi leirat, 1652. március 20. SснмIDT: i. m., 4/749. 
azért is szükség lehetett, mert a kinevezendő hivatalnokkal járó újabb kiadásokat az uralkodóval jóvá kellett hagyatni. ${ }^{15} \mathrm{Az}$ Udvari Kamara azt is előírta, hogy a tisztségek betöltése előtt a főkamaragróf kérje ki a főtisztek véleményét, és ezzel együtt terjessze fel javaslatait úgy, hogy mindig három személy közül lehessen választani. ${ }^{16}$ A vélemények kikérése azért is nagyon fontos lehetett, mert a bányatisztek az ügyesebb vájárok közül kerültek ki. ${ }^{17}$

A 18. században, amikor a hierarchikusan kiépített bürokrácia megjelent, ${ }^{18}$ és a központi kormányzat vonatkozásában változások következtek be, a tisztviselők alkalmazására is újabb utasítások kerültek kiadásra. 1747-ben a tisztjelöltek és gyakornokok alkalmasságának vizsgálatát és alkalmazásának jóváhagyását a Pénzverés- és Bányaigazgatási Udvari Kollégium ${ }^{19}$ hatáskörébe vonták. A kollégiumhoz való felterjesztésbe bele kellett foglalni a jelentkező nevét, életkorát, hogy milyen tisztségeket töltött be korábban, honnan származott, milyen nemzetben, milyen státuszban állt, milyen volt a származása, milyen alkalmazásba szeretett volna kerülni,

${ }^{15}$ Az Udvari Kamara dekrétuma, 1661. július 16. SchмiDT: i. m., 5/34. Péch Antal például beszámol arról, hogy 1680. november 26-án a fökamaragróf arról értesítette a főtiszteket, hogy „ő Felsége Ethaesius Mátyás eddigi bányamérnököt segédbányatisztté kinevezte hetenkint 2 frt fizetéssel” (lásd PÉCH Antal: Alsó-Magyarország bányamívelésének története III, MTSZ Házi NY. Budapest, 1967, 64).

16 PÉCH (1967): i. m., 64.

17 Miralovits János: Munkásjog az 1573. évi Miksa-féle bányarendtartásban. Bányászati és Kohászati Lapok, 1934, (67) 106-114, 128-134, 153-158, 178-182, 222-227, 111. Mihalovits megállapítását teljességgel alátámasztja Hechengarten alkamaragróf életrajza: Bartholomäus Ludwig Edler von Hechengarten azért került a tiroli Oberndorfból 18 évesen az apjával Oravicára, mert 1720-ban tiroli bányászokat telepítettek át a Temesi bánság területére. Hechengarten öt éven keresztül tanuló, majd szakmányvájár, végül ércbányász volt. Két évig az aknákban az ácsmunkát végezte, három évig Majdanpeken felőrként alkalmazták, 1734-ben pedig már bányamester volt Csernosticán. Az 1737-39-es török háború idején a bányavédő egységeket vezényelte. 1740-ben a tönkretett bánáti bányák rendbetételének felügyelője lett, majd föbányamesterré és inspektorrá nevezték ki a bánáti bányák fölé. 1747-ben bányatanácsos, alkamaragróf, és első főkamaragrófi ülnök lett (lásd PüRSTL, Ludwig: Bartholomäus Ludwig von Hechengarten - ein grosser Oberndorfer, Chronik von Oberndorf, 1991, http://www.sagen.at/doku/bergbau/Edler_von_Hechengarten.html, 2020. április 2). Egy 1749-ben kiadott királyi leiratból pedig kiderül, hogy azokat a személyeket látták szívesen a bányatisztnek jelentkezők között, akik vájárok voltak, hiszen ők értettek a szakmához, és a munkások is szívesebben elfogadták az utasításaikat: „A bányatiszti és a bányaadjunktusi állásokat a jövőben csak oly egyének számára tartjuk fenn, akik farbörös bányászok, vagyis, akik a bányában ék és kalapáccsal a kezükben, jól és szorgalmasan, reális értelemben dolgoztak, s ezután a felöri teendőket kitünően látták el" (lásd királyi leirat, 1749. július 27. ScHMIDT: 8/99, ford.: MıHALOVITS János: Az első magyar bányatisztképző iskolák alapítása. Bányászati és Kohászati Lapok, 1931/3-4. [64] 49-54, 73-78, 74). A leiratban az is olvasható, hogy a királyné egy vájár fiát felvette a gyakornokok közé, mivel az apa, és maga a fiú is szorgalmasan dolgoztak a bányákban. Esetében még attól is eltekintettek, hogy nem volt katolikus.

${ }^{18}$ A 18. században a Habsburgok egy új típusú igazgatási rendszer kiépítésével váltották fel az addigi kamarai irányítást. A törökök kiszorítása az ország területéröl ugyanis lehetővé tette az egységes, központosított igazgatás kiépítését. Ennek során a Habsburg udvar egy pókhálóhoz hasonlatos, zárt bürokráciát hozott létre, amelyben minden egyes területnek saját vezetője volt, végső fokon azonban minden szál egy kézben, elsősorban a Főkamaragrófi Hivatalban, és az e felett, a montángazdaság irányítására az udvarban felállított szervnél, végső soron az uralkodó kezében futott össze. Az ország területén bányakerületeket alakítottak ki, amelyek élén a főbányahatóságok álltak. Ezeknek a főbányahatóságoknak alárendelten a jelentősebb bányavárosokban müködtek azok a hivatalok, amelyek első fokon intézték a bányaigazgatási teendőket.

19 Mária Terézia által, a központi bányaigazgatás átszervezése során, az 1745. október 31-én kiadott alapítólevéllel az udvarban felállított, három tanácsosból álló, szakigazgatási szerv (lásd császári leirat, 1745. november 6., SCHMIDT: i. m., 7/81). 
az eddigi praxisait és funkcióit. A kollégium pedig eldöntötte, hogy a fökamaragróf alá tartozó hivatalnokok közé ki, milyen fizetéssel és ellátással nyerjen felvételt. A kollégium annak eldöntését is magának tartotta fenn, hogy a tisztjelöltek és gyakornokok milyen tudást sajátítsanak el. ${ }^{20} \mathrm{Az}$ előléptetésekre való felterjesztés esetén arról is nyilatkozni kellett, hogy a hivatalnoknak milyen képzettsége volt korábban, illetöleg milyen képzettség és rang megszerzésére számíthatott a jövőben. ${ }^{21}$

A rokonsági kapcsolat csak az alkalmazott hivatalnokok esetében volt kizáró ok, a gyakornokoknál nem. ${ }^{22} \mathrm{Az}$ állások meghirdetésébe pontosan bele kellett foglalni a fizetés összegét, az elnyerhető elönyöket, és azt, hogy milyen rangú hivatalnok válik abból, aki betölti az állást. ${ }^{23} \mathrm{~A}$ tisztviselök díjazására vonatkozóan az egyes bányahivatalokra vonatkozó rendeletek nyújtják a legtöbb információt. Egy-egy hivatal felállításakor vagy átszervezésekor ugyanis meghatározták, hogy a hivatalban milyen tisztviselök, mekkora bérért látták el a feladatukat, hiszen a költségeket elöre kikalkulálták a Habsburg udvarban. Arra is találunk azonban adatot, hogy a Kamara nem fizette ki a tisztviselőket, és számon tartotta a feléjük törlesztendő adósságot. ${ }^{24}$

\section{A hivatalnokok jogviszonyával és összeférhetetlenségével kapcsolatos szabályok}

A hivatalnokokat nemcsak a kinevezés során, hanem a hivatali idejük alatt is az udvar centralizált felügyelete alatt kívánták tartani. A hivatalnokok ezért teljesen kívül álltak az országban szokásos hivatali renden, az összes rendtöl és közigazgatási szervtöl függetlenül müködtek. Ezzel kapcsolatban már a 17. században is születtek rendeletek. Így azoknak a hivatalnokoknak, akiknek Selmecbányán volt házuk, az általános városi adón kívül más illetéket nem kellett fizetniük, és a város joghatósága helyett a központi kamara alá tartoztak, ${ }^{25}$ még tanúként sem voltak kötelesek a városi bíróság előtt megjelenni. ${ }^{26} \mathrm{Ez}$ utóbbi rendelkezést később úgy módosították, hogy ha egy bányatisztviselő idézést kapott a polgári bíróságtól, vallomását a bányabíróság vette fel, és az erröl felvett jegyzéket küldték meg az ügy elbírálásához. ${ }^{27}$

Ezt a rendelkezést később Mária Terézia a Selmecbányának írt rescriptumában is megismételte, és előírta, hogy azoknak a tisztviselőknek, akik a bányavárosban laktak, hitlevelet kellett aláíniuk, amelyben megfogadták, hogy a birtokukra eső városi terheket viselik, szükség esetén segítik a városi elöljárókat, a városi szabadal-

\footnotetext{
${ }^{20}$ Az Udvari Bizottság dekrétuma, 1747. január 7. SCHMIDT: i. m., 7/140.

${ }^{21}$ Az Udvari Kamara dekrétuma, 1776. június 7. ScHMIDT: i. m., 14/73.

${ }^{22}$ Az Udvari Kamara dekrétuma, 1769. április 29. ScHMIDT: i. m., 13/140.

${ }^{23}$ Az Udvari Kamara dekrétuma, 1773. július 30. Schmidt: i. m., 13/385.

24 Így 1739. február 26-án kimutatták, hogy az alsó-magyarországi tisztviselőknek 2032 forint 45 krajcár járt. Lásd PÉCH (1967): i. m., 189.

${ }^{25}$ Az Alsó-Ausztriai Kamara rendelete a selmecbányai bíró és tanács számára, 1605. április 22., ScHMIDT: i. m., 3/535, PÉcH (1887): i. m., 51. 1605-ben az Alsó-Ausztriai Kamara gyakorolt a hivatalnokok felett joghatóságot. A Kamara a rendeletet Selmecbánya bírájának és tanácsának címezte, így lényegében eltiltotta őket attól, hogy az ott lakó bányászati hivatalnokoktól városi kötelezettségek teljesítését követeljék.

${ }^{26}$ Kamarai rendelet a körmöci alkamaragróf számára, 1608. június 30. SCHMIDT: i. m., 4/112, PÉCH (1887): i. m., 82. A rendeletben a hivatalnokot egy gyilkossági ügyben való tanúskodás alól mentették fel.

${ }^{27}$ Az Udvari Kamara dekrétuma, 1764. október 29. SCHMIDT: i. m., 12/92.
} 
makat tiszteletben tartják, de a kamara joghatósága alá tartoznak. ${ }^{28}$ Azok a kincstári tisztviselők azonban, akik egyúttal polgárok is voltak, polgári birtokkal is rendelkeztek, vagy polgári hivatalt is viseltek, ${ }^{29}$ személyes ügyeikben a bányabíróság, polgári birtokaikra vonatkozó ügyeikben viszont a polgári hatóság alá tartoztak. ${ }^{30}$ Maguk a bányavárosok is az Alsó-Ausztriai Kamara alá tartoztak. ${ }^{31}$

A selmeci pénztárnok számára Rudolf által kiadott instrukcióból megtudhatjuk, hogy a tisztviselőknek hivatalba lépésükkor azonnal esküt kellett tenniük, és feltétlen engedelmességgel tartoztak a hivatal vezetőjének. Az instrukció szerint a hivatalnokoknak reggel 6-tól 10-ig és délután 1-től 5-ig kellett a hivatalban tartózkodniuk. Ha távozni akartak, szintén ki kellett kérniük a vezető beleegyezését, három napnál hosszabb távolléthez azonban az Alsó-Ausztriai Kamara hozzájárulására volt szükségük. ${ }^{32}$

A tisztviselők közötti rangsor a külsőségekben is megnyilvánult. A bányavárosokba az udvar által kiküldött, és a helybéli tisztviselök közötti rangsornak megfelelően kellett haladniuk az ünnepi menetekben, és a tanácskozásokon az asztalnál helyet foglalniuk. Egy rendelet szerint a bányavárosokba küldött udvari kamarai számtanácsosoknak a helybéli pénztárnok előtt kellett menniük, a pénztárnok után pedig az udvari számtisztek következtek, majd utánuk a többi helybéli tisztviselö. Az udvarból küldött hivatalnokoknak nem kellett a tanácskozásokon az asztalnál helyet biztosítani, mert nem volt tanácskozási joguk, hanem mint vendégek foglaltak helyet a többi tiszt között. Az udvari küldöttek élelmezésére a helyiek személyenként 50 krajcárt számolhattak el. ${ }^{33}$

Mária Terézia rescriptuma szerint a hivatalnokoknak nyilvános ünnepségek alkalmával is a rangjuk szerint megfelelő helyen kellett haladniuk. Így a kincstári főbb tisztviselőknek lovas kíséretükkel a jobb oldalon kellett haladniuk a kamara zászlója alatt. Körmenetek alkalmával a kamarai főtisztviselők, így a főpénztárnok és a könyvelő, a városi hatóságok előtt mentek, a bányabíró pedig a városi bíró előtt haladt. A többi tiszt a tanácsbeliekkel a koruknak megfelelő sorrendben követte őket. ${ }^{34}$

A hivatalok többszöri átszervezése miatt, és a tisztviselők feladatainak változásával egyes esetekben egyértelművé kellett tenni a hivatalnokok közötti rangsort. Amikor a körmöci pénzverde pénzvizsgálója a föhivatalnokok közé emelkedett, rögzítették, hogy a bányamester rangban mégis felette állt. ${ }^{35}$

\footnotetext{
${ }^{28}$ Mária Terézia egyik legfontosabb, 1747. június 16-án Selmecbányához intézett rescriptuma, amely a városi és a bányabíróság hatáskörét rendezte. Lásd királyi leirat, 1747. június 16., 10. pont. ScHMIDT: i. m., 7/238; PÉCH (1967): i. m., 226.

${ }^{29}$ Ilyenek voltak a bányabírók, akik egyúttal a városi tanácsnak is tagjai voltak. Egy rendelet szerint azonban a bányatisztek csak az Udvari Kollégium engedélye alapján vállalhattak tisztséget a bányavárosok tanácsaiban. Lásd a Pénzverés- és Bányaigazgatási Udvari Kollégium dekrétumát, 1752. március 21. ScHMIDT: i. m., $10 / 71$.

${ }^{30}$ Királyi leirat, 1747. június 16. 8. pont. Schmidt: i. m., 7/238, PÉCH (1967): i. m., 225-226.

${ }^{31}$ Az Udvari Kamara rendelete, 1612. október 22. SCHMIDT: i. m., 4/304.

${ }^{32}$ A selmecbányai pénztárnok részére kiadott királyi instrukció, 1601. november 13. SCHMIDT: i. m., 3/348; PÉCH (1887): i. m., 14.

${ }^{33}$ A Pénzverés- és Bányaigazgatási Udvari Kollégium dekrétuma, 1747. április 21. ScHMIDT: i. m., 7/155.

${ }^{34}$ Királyi leirat, 1747. június 16. 32. pont. SchMIDT: i. m., 7/238; PÉCH (1967): i. m., 230.

${ }^{35}$ Az Udvari Kamara dekrétuma, 1774. június 14. ScHMIDT: i. m., 13/403.
} 
Az Udvari Kamara valószínüleg a hivatalnokok szakértelmének megkérdőjelezhetetlenségére törekedve, és az egységes szabályozás veszélyeztetésének elkerülése érdekében, ${ }^{36}$ felügyelni kívánta a tisztviselők tudományos tevékenységét is. Így az Udvari Kamara előírta, hogy engedélye nélkül egy hivatalnok sem jelentethet meg nyomtatásban közleményt a bányakezelésre, bányagépekre, a bányarendtartásra vagy a bányajogra vonatkozóan. Aki ezt a rendelkezést nem tartotta be, azt elbocsátották az állásából. ${ }^{37}$ Az Udvari Kamara engedélye nélkül - büntetés terhe mellett - tilos volt a tisztviselőknek mások számára gépmodelleket vagy leírásokat készíteni, vagy ezeket nyomtatásban megjelentetni. ${ }^{38}$ Ugyanígy tilos volt ásványtani vagy tüzzel végzett kísérletekről szóló tanulmányt közzétenni a Főkamaragrófi Hivatal engedélye nélkül. ${ }^{39}$

A tisztviselőkre vonatkozó összeférhetetlenségi szabályok egyrészt a bányamüvelés tilalmára, másrészt egyéb foglalkozástól való eltiltásra vonatkoztak. A bányászati adminisztrációban részt vevő hivatalnokoknak már a Miksa-féle bányarendtartás is megtiltotta, hogy bányamúveléssel foglalkozzanak a hozzájuk tartozó területeken. ${ }^{40} \mathrm{~A}$ kamarai tisztviselők nem vehettek részt sem közvetlenül, sem közvetve a bányaművelésben, bányászattal összefüggő üzleti vállalkozásban, ${ }^{41}$ nem foglalkozhattak fémbeváltással, ${ }^{42}$ ügynökösködéssel. ${ }^{43}$

Egy udvari kamarai rendeletből azonban kiderül, hogy a tisztviselőknek a tilalom ellenére részesedésük volt bányatársaságokban, sőt a főkamaragróf is bányarészeket ${ }^{44}$ kívánt szerezni. Az Udvari Kamara azonban ezt továbbra sem engedélyezte, és előírta, hogy jegyzéket kell összeállítani a bányarésszel rendelkezőkről, és meg kell találni a módját ezeknek a részeknek az értékesítésére. ${ }^{45} \mathrm{~A}$ szomolnoki föbányahivatal átszervezésére kiadott királyi leiratban konkrétan is szerepel, hogy a hivatalnokoknak mindenféle bányarészesedés megszerzése tiltott volt, és akik ilyennel rendelkeztek, azoknak el kellett idegeníteniük részeiket, vagy azt a kincstár

${ }^{36}$ A központi igazgatás a 18. század folyamán többször változott. A pénzverési és bányaügyek azonban 1760-ban újra az Udvari Kamara kompetenciájába kerültek, és a Hofkammer 1848-ban történő megszünéséig ott is maradtak (lásd az Udvari Kamara dekrétumát, 1760. január 9. ScHMIDT: i. m., 11/22). A kerületi föbányahatóságoknak küldött rendeletek kibocsátóinak megjelölése alapján jól nyomon lehet követni a központi hivatalok változásait.

${ }^{37}$ Az Udvari Kamara dekrétuma, 1772. március 20. ScHMIDT: i. m., $13 / 348$.

${ }^{38}$ Az Udvari Kamara dekrétuma, 1772. április 4. ScHMIDT: i. m., 13/352.

${ }^{39}$ Az Udvari Kamara dekrétuma, 1772. április 18. ScнміDт: i. m., 13/354. A rendelet szövege szerint ezeket a tanulmányokat előbb megvizsgáltatták Scopoli professzorral. Giovanni Antonia Cavalese Scopoli 1769 és 1779 között, tehát a rendelet kiadásának időpontjában a selmecbányai akadémia kémia-kohászat-ásványtan tanszékének tanára és vezetője volt.

${ }^{40}$ MBO I. 2; XXVII. 1. §. A bányarendtartás felsorolja, mely tisztviselök tartoztak a tilalom alá. Ezek a következők: főkamaragróf, rézkereskedelem gondnoka, alkamaragrófok, ezeknek alárendelt tisztviselők, bányamester, bányabíró, bányatiszt, bányamérnök, ércosztó, bányabírósági írnok, esküdtek, bírósági szolgák.

${ }^{41}$ Királyi leirat, 1626. október 16. ScHMIDT: i. m., 4/458.

42 Királyi leirat, 1602. október 8. ScHMIDT: i. m., 3/362.

${ }^{43}$ Királyi leirat, 1626. október 16. SchMIDT: i. m., 4/457, PÉCH (1887): i. m., 210.

${ }^{44}$ A magánkézben lévő bányaművek voltak a bányatársaságok. A részvénytársaságokkal rokonságot mutató bányatársaságokban való részesedést a bányarészek, a kuxok testesítették meg.

${ }^{45}$ Az Udvari Kamara dekrétuma, 1724. június 15. SchmidT: i. m., 6/223, PÉch (1967): i. m., 131. 
bevonta, különben elvesztették az állásukat. ${ }^{46} \mathrm{~A}$ bánáti bányakerület területén az alacsonyabb rangú tisztviselöknek megengedték, hogy szolgálati helyükön kívül fekvő bányaművekben részesedést szerezzenek, a főtisztviselőknek azonban ezt mindenhol megtiltották. ${ }^{47}$

A bányaművekben való részesedés tilalmát a Bánya- és Pénzverésügyi Igazgatóság $^{48}$ a tisztviselő feleségére, gyermekeire, fiatalkorú testvéreire is kiterjesztette abban a körzetben, ahol a hivatalnok az állást betöltötte. ${ }^{49}$ Ezeket a tilalmakat később is fenntartották azzal, hogy nemcsak a bányamesterek, bányamérők, kémlészek, hanem a bányasáfárok sem folytathattak bányászati tevékenységet, csak a kisebb bányahivatalnokoknak engedték ezt meg. A részesedés szerzésének engedélyezése azonban nem jelentette azt, hogy a kisebb hivatalnokok a bányatársaságoknál tisztséget vállalhattak. Így a jegyzőkönyvvezetők sem vállalhattak megbízást a társaságoknál. ${ }^{50}$

Azt a területet, ahol teljesen tilos volt a részesedés szerzése, a bányakerülettel azonosították. Így például a selmecbányai bányamérnökök nem szerezhettek részesedést a bélabányai bányamúnél, mivel mindkét város az alsó-magyarországi bányakörzetben a Fökamaragrófi Hivatal alá tartozott. ${ }^{51}$ Ugyanezen elv szerint a Temesi bánságban a tisztviselöknek el kellett adniuk a bányarészüket, hiába szolgáltak más helyen, mint ahol a bánya volt, mivel mindkettő egy bányakerülethez tartozott. ${ }^{52} \mathrm{~A}$ Temesi bánságban a magánbányászatban alkalmazott tisztviselők, akik számlázással foglalkoztak, így a faktorok, bánya-, kohó- és szertárírnokok sem rendelkezhettek bányarészekkel a saját müködési területükön. ${ }^{53} \mathrm{~A}$ bányaüzemeknél alkalmazott orvosoknak azonban még a saját szolgálati helyükön is lehetett részesedésük a bányában, mivel ők a gyógyítást végezték, nem a bányákkal kapcsolatos ügyleteket intézték. ${ }^{54}$

1776-ban az Udvari Kamara megtiltotta a hivatalnokoknak, hogy magánüzemekben, bérleményekben, kereskedésekben, kereskedő társaságokban részesedést szerezzenek. Ha azonban egy hivatalnok már rendelkezett ilyen részesedéssel, azt be kellett jelentenie; az erről szóló feljegyzést a főkamaragróf őrizte. Saját birtokon a saját ellátásuk érdekében azonban felállíthattak üzemeket, de idegen birtokon nem. ${ }^{55}$

${ }^{46}$ Királyi leirat, 1749. február 11. ScHMIDT: i. m., 8/3. 3. 22. pont. Ezt az előírást 1751-ben megismételték, mert a tisztviselők továbbra is rendelkeztek bányarészekkel (lásd: a Pénzverés- és Bányaigazgatási Udvari Kollégium dekrétuma, 1751. április 29. ScHMIDT: i. m., 10/3).

${ }^{47}$ A Pénzverés- és Bányaigazgatási Udvari Kollégium dekrétuma, 1751. november 29. ScHMIDT: i. m., 10/34.

${ }^{48}$ A Pénzverés- és Bányaigazgatási Udvari Kollégium helyébe lépő, 1757-ben felállított szakigazgatási szerv (lásd a Bánya- és Pénzverésügyi Udvari Bizottság dekrétumát, 1757. január 26. ScHMIDT: i. m., 10/462).

${ }^{49}$ A Bánya- és Pénzverésügyi Udvari Igazgatóság dekrétuma, 1759. július 11. ScHmidT: i. m., 11/11. A rendelet kiadására egy konkrét esettel kapcsolatosan került sor, amelyben egy tisztviselő a tilalom kikerülése céljából saját gyerekére íratta át a bányarészeit.

${ }^{50}$ Az Udvari Kamara dekrétuma, 1775. április 21. Schmidт: i. m., 14/6. A rendelet konkrétan is megnevezi, hogy a dognácskai ezüstbánya-társaságnál nem vállalhatott tisztséget az ottani hivatalnál dolgozó jegyzőkönyvvezető, Anton Untergutsch.

${ }^{51}$ Az Udvari Kamara dekrétuma, 1760. október 29. ScHMIDT: i. m., 11/190.

52 Az Udvari Kamara dekrétuma, 1761. december 16. ScHMIDT: i. m., 11/478.

${ }^{53}$ Az Udvari Kamara dekrétuma, 1760. szeptember 30. SCHMIDT: i. m., 11/25.

${ }^{54}$ Az Udvari Kamara dekrétuma, 1777. január 24. SchміDт: i. m., 11/129.

${ }^{55}$ Az Udvari Kamara dekrétuma, 1776. április 20. ScHMIDT: i. m., 14/61. 
A szigorú összeférhetetlenségi szabályokat II. József idején enyhítette az Udvari Kamara. Így azoknak a volt tisztviselőknek, illetve azok feleségének és gyermekének, akik már nem töltöttek be ténylegesen hivatalt, megengedték, hogy részesedésük legyen a bányákban, és általános engedélyt adtak a bányakörzeten kívüli részesedés megtartásához a tisztviselőknek, s azok feleségének és gyermekének is. ${ }^{56}$ Abban a kerületben, ahol a tisztviselő müködött, engedélyt kellett kérni a bányarészek birtoklásához a föbányahivataltól, különben a kincstár elvette a részeket. ${ }^{57}$ A későbbiekben hozott rendeletek is ezt az elvet követték.

1792-ben az Udvari Kamara a bányabíróságok alkalmazottainak kivételével megengedte az erdélyi hivatalnokoknak, hogy a rézbányászatban részt vegyenek. Erre az engedményre a bányavállalkozók fogyatkozása miatt volt szükség. ${ }^{58}$

\section{A hivatalnokok anyagi és büntetőjogi felelössége}

A hivatalokban dolgozó tisztviselők jelentős összegekkel gazdálkodtak, ezenfelül szakértelmüktől függtek a montángazdaság bevételei is. A főkamaragróf ezért 1703ban utasította a tisztviselőit, hogy a kincstár érdekeit a legnagyobb szorgalommal, húséggel és jó gazdálkodással mozdítsák elő. ${ }^{59}$ A hivatalnokoknak mindenképpen megfelelő képzettséggel kellett rendelkezniük, hiszen ellenkező esetben veszteséget okoztak volna a kincstárnak. A hanyag, szakszerütlen eljárásokat, illetőleg a szándékos károkozásokat a Habsburg udvar a leendő hivatalnok részéről történő óvadék fizettetésével és reverzálisok aláíratásával is igyekezett megelőzni. A reverzálisok olyan nyilatkozatok voltak, amelyekben a tisztviselők egyrészt megfogadták, hogy a kincstári érdekeket hủségesen szolgálni fogják, másrészt lemondtak olyan jogaikról, amelyek a magyar szabályok alapján megakadályozhatták volna a felelősségre vonásukat a bányászati jogszolgáltatás által.

\subsection{A reverzálisok}

I. Lipót már a főkamargrófnak 1660. június 14-én küldött rendeletében leírta, hogy a kamarai elszámolásokban a szabálytalanságok megszüntetése érdekében a hivatalnokok adjanak kauciót és reverzálist. A kaució összegéröl nem rendelkezett az uralkodó, de a rendelet felsorolta, hogy melyek azok a hivatalnokok, akiktől ezt a főkamaragrófnak be kellett szednie. Ez a felsorolás azért is érdekes, mert így képet kaphatunk arról, mely hivatalnokok foglalkoztak pénzkezeléssel. A rendeletből azonban hiányzik, hogy a reverzálisnak mit kellett tartalmaznia. ${ }^{60}$

${ }^{56} \mathrm{Az}$ Udvari Kamara dekrétuma, 1782. február 13. SCHMIDT: i. m., 15/262.

${ }^{57}$ Az Udvari Kamara dekrétuma, 1784. július 10. ScHmidT: i. m., 16/325.

${ }^{58}$ Az Udvari Kamara dekrétuma, 1792. október 9. SCHMIDT: i. m., 18/378.

59 Tanácsi dekrétum, 1703. április 20. SCHMIDT: i. m., 5/792. Ezt a rendeletet azért bocsátotta ki a fökamaragróf, mert a selmecbányai kamara ügyeinek vizsgálata során arra jutottak, hogy a termelés apadt, a költségek pedig növekedtek. A rendelet az elszámolásra vonatkozóan is tartalmazott szabályokat.

${ }^{60}$ Királyi leirat, 1660. június 14. SCHMIDT: i. m., 5/23; PÉCH (1967): i. m., 35. A rendelet által felsorolt hivatalnokok a következök: A körmöci kamaránál: alkamaragróf, könyvelö, a Goldkunsthandlung (a körmöcbányai kincstári 
A reverzálisokra az Udvari Kamara 1776-ban adott ki egységesen formulát, amelyben a következőket fogadták meg a tisztviselők:

Reverzális: Miután a pénzverés- és bányaügyekben eljáró Udvari Kamara nekem, alulírottnak, ... állást juttatta, és a hivatallal járó díjazást ... kaució lefizetése mellett biztosította, fogadom írásban, jogi helytállást vállalva, hogy a megjelölt hivatalt hüségesen, szorgalmasan és igyekvően, a hivatali instrukcióknak megfelelően fogom ellátni. Lehetőleg a kincstár hasznát növelem, amelynek kárát és hátrányait teljes erőmből próbálom elhárítani, az egész rám bízott, pénzbeli és természetbeni javakról, időről időre, elszámolást adok, amelyek a könyvelési hiányosságokat és kintlévőségeket megvilágítják. Egyúttal az én hibámból, hanyagságomból és hűtlenségemből eredő rövid vagy hosszú ideig tartó veszteségekért vagy károkért felelek. A császári és királyi Pénzverés- és Bányaügyi Kamarának - amelynek a jurisdictiója alá tartozom, amíg a számadásait vezetem, és amíg az elszámolásaimról az abszolutóriumot átveszi, akkor is, ha már kiléptem a kamarai hivatalból és egy másik hivatást választottam - teljes hatalmában áll, hogy az én hibámból a kincstárnak okozott kárért, a kártalanítást a letétbe helyezett hivatali kauciómból, vagy ha az nem lenne elég, a birtokaimból és ingóságaimból kivétel nélkül kielégítse. Ez a jog akkor is megilleti, ha a bizonyítható veszteséget és hátrányt magasabb parancsnak engedve eredményeztem. Akkor is, ha az ellenem kiadott parancsok teljesítése rendi állásba ütközne, ha a személyemet a nemesi és más előjogok miatt bírósági eljárás nélkül nem lehetne letartóztatni, engem mégis minden időben és helyen le lehet tartóztatni, ahol ez alkalmas. Egyúttal minden nemesi és egyéb előjogomról az előbbi esetekre lemondok, hogy amíg a számlákért felelek és veszteséget okozhatok, azok nem menthetnek fel, hanem minden esetben a k.k. Udvari Kamara pénzverés- és bányaügyi esetekben való jurisdictiójánál kérhetek segítséget. Amint más esetekben is, ha megszegvén eskümet, a pénztárat károsítom vagy más hütlenséget követek el, az osztrák örökös tartományokban 1753-ban kihirdetett, és ebben az országban is bevezetett, elolvasott és megértett büntető pátensnek ${ }^{61}$ és a kamarai judikatúrának alávetem magam. Az itt lévő okiratot saját kezűleg aláírom. ${ }^{62}$

Ebből a formulából megtudhatjuk, hogy nemesek is vállaltak hivatali tisztséget, a nemesi előjogok azonban nem érvényesültek az anyagi felelősséget vállalók esetén. Míg az egyik nemesi előjog szerint a nemeseket csak bírói eljárás alapján lehetett letartóztatni, ${ }^{63}$ a tisztviselő lemondott erről az előjogról. A Tripartitum szerint a nemest megfelelő eljárás nélkül senki, sehol le nem tartóztathatta, a reverzális azonban

bányászat) gondnoka, pénzbecsőr, főcimentező, szertárnok. A selmeci kamaránál: föpénztárnok, könyvelő, ellenőr, kohótiszt, szertárnok, főaranyválató. A besztercebányai kamaránál: prefektus, pénztárnok, könyvelő, ellenőr, bánya- és szertárírnok, Úrvölgyön a sáfár és az írnok az új kohóban, a sáfár Óhegyen, a sáfár és az írnok Mostenitzen, a sáfár Tajován, a sáfár a rézhámorban, a sáfár Rónitzon, az építész és a gereblyeírnok, a sáfár Libetbányán, a sáfár az új vaspörölydében, az esküdt kémlész és az ezüstégető a kamaraházban, a bányaszertárnok és a fő tizedszedő Turczon.

${ }^{61}$ A pátens a hivatalnokok büntetőjogi felelősségét alapozta meg, lásd lentebb.

${ }^{62}$ Az Udvari Kamara dekrétuma, 1776. november 22. SchmidT: i. m., 14/114 (fordítás: G. M.).

63 „1222. évi Aranybulla 2. cikkely: Ezt is akarjuk, hogy a nemes embert sem mi, sem az utánunk való királyok soha meg ne fogják, vagy meg ne nyomorítsák valamely hatalmas kedvéért, hanem ha előbb perbe hivatott és rendes úton törvényt láttak reá" (lásd CJH I. 1899, 133). A Tripartitum a négy sarkalatos nemesi jog között ezt a privilégiumot az első helyen rögzíti: „Az első abban áll, hogy őket, ha csak előbb megidézve vagy pörbe hiva és a törvénykezési rend útján elmarasztalva nem lettek, bárkinek folyamodására, vádaskodására vagy 
éppen azt fogalmazta meg, hogy valószínűleg a bányáknál szolgálatot teljesítő hajdúk bárhol, bármikor elfoghatták a nemesi ranggal rendelkező hivatalnokot. Werbőczy felsorol olyan eseteket is, amikor a nemesi kiváltság nem mentesített a letartóztatás alól; ilyen volt a szándékos emberölés, gyújtogatás, lopás, rablás, útonállás, erőszakos paráznaság. Az Udvari Kamara így a legsúlyosabb búncselekményekkel azonos jogkövetkezményeket füzött a kincstár megkárosításához, bár ebben az esetben a hivatalnok reverzálisban történő lemondása volt szükséges a nemesi előjog mellőzéséhez. A nemesi ranggal rendelkező tisztviselő arról az előjogáról is lemondott, hogy felette csak a király vagy a nevében eljáró nádor ítélkezhetett, alávetette magát a bányabírósági eljárásnak. ${ }^{64}$

A nemesi ranggal járó jogosultságokkal szemben azonban nemcsak a lemondó nyilatkozatok által, hanem rendeleti úton is védekezni próbált a Habsburg udvar. A Pénzverés- és Bányaigazgatási Udvari Kollégium már 1753-ban kiadott egy rendeletet, amelyben előírták, hogy ha a Főkamaragrófi Hivatalban vagy az alárendelt hivatalnokok közül valaki nemesi rangot kíván szerezni, ahhoz előbb be kell szereznie a hivatal egyetértését, ellenkező esetben felmentették szolgálata alól. A rendelet azt is előírta, hogy a már nemesi rangban lévők adjanak reverzálist arról, hogy lemondanak nemesi előjogaikról. ${ }^{65}$ Az Udvari Kamara óvatossága a nemesi rang megszerzésével kapcsolatban azzal is magyarázható, hogy a magyar nemesség örömmel vette, ha az általában idegen származású hivatalnokok nemesi rangot szereztek, mert ezzel rendi, nemzeti hatás alá kerültek. ${ }^{66}$ Egy 1779-ben kiadott rendelet szerint abban az esetben, ha a tisztviselőt áthelyezték, sem neki, sem feleségének nem kellett új reverzálist adnia. ${ }^{67}$

A magyar szokásjog és a törvénycikkek számos előjogot biztosítottak a feleségnek, amelyeket a házastárs vagyonából kellett kielégíteni. A feleségnek járó juttatásokat mindenképpen ki kellett adni a házastárs vagyonából, még az örökösöket is terhelte ez a kötelezettség. Annak megakadályozására, hogy a feleség követelései veszélyeztessék a kincstárnak járó kártérítési kötelezettség kielégítését, a hivatalnok feleségének is ki kellett töltenie egy reverzálist, amelyben lemondott előjogairól, és a kincstárnak adta át az első helyet a tisztviselő vagyonával szembeni követelések rangsorában. A feleség által kiállítandó nyilatkozatra is kiadott a kamara formulát, mely a következőképpen szólt:

kérésére személyökben senki és sehol le nem tartóztathatja” (HK. I. 9, 1. §, Id. WERBőczY István: Tripartitum. Fordította Csiky Kálmán, 1894. Téka, Budapest, 1990, 72, a továbbiakban HK.).

64 „1222. évi Aranybulla 8. cikkely: A nádorispán minden ember dolgában, ki országunkbeli, különbség nélkül itéljen. 1. § De nemesek perét, ha fejök vesztébe vagy birtokuk veszedelmébe jár, a király híre nélkül el ne végezhesse” (lásd CJH I. 135). HK I. 9. 4. §: „A második szabadság abban áll, hogy az egész ország nemesei a törvényesen megkoronázott királyon kívül senkinek másnak hatalma alatt nem állanak; sőt maga fejedelmünk is valakinek puszta panaszára vagy rosszakaratú besúgására, közülük senkit a törvény rendes útján kívül és a másik fél meghallgatása nélkül, személyében vagy vagyonában a maga rendes hatalmánál fogva nem háborithat" (lásd HK, 73).

${ }^{65}$ A Pénzverés- és Bányaigazgatási Udvari Kollégium dekrétuma, 1753. október 21. ScHMIDT: i. m., 10/184.

${ }^{66}$ FALLENBÜCHL Zoltán: A Magyar Kamara tisztviselői a XVIII. században. Levéltári Közlemények, 1970 (41), 259-336, 280.

${ }^{67}$ Az Udvari Kamara dekrétuma, 1779. február 5. ScHMIDT: i. m., 14/257. 
A feleség reverzálisa: Nyilatkozom és kötelezem magam, hogy azokban az esetekben, amikor a házastársam a kegyelmesen rábízott hivatalában elszámolási rendellenességeket találtak, vagy az ő hibája, hanyagsága vagy hűtlensége miatt, vagy ha a rábízott javakban veszteséget okozott, a pénzverés- és bányaügyekben eljáró Udvari Kamara a kincstár kártalanítását az ő birtokaiból és ingóságaiból - megelőzve a vagyonban lévő, engem házassági szerződés, pactis dotalitiis, vagy más, nőket megillető igényeket - teljes mértékben kielégítse. Az előbb említett esetekben az országos törvényekben biztosított női előjogokról is teljes mértékben lemondok. Ezek alapján soha semmilyen módon nem fogok kártérítést követelni. Az itt lévő reverzális okiratot a kincstár biztosítása érdekében önként és jól átgondoltan aláírom. ${ }^{68}$

A feleségnek férje halála után ugyanis ki kellett adni a hozományát és a hitbérét, ${ }^{69}$ megillette a jegyajándék, férje életében pedig megfelelő tartásra volt jogosult. ${ }^{70} \mathrm{~A}$ nőknek lehetett különvagyona is, amelyet a házasság alatt, de a házasságra tekintet nélkül szereztek, királyi adomány, öröklés vagy jogügylet útján. A nőt a közösen szerzett vagyon fele is megillette. Egy 1768-ban kiadott rendeletben megadott minta szerint a nőnek a következőket kellett nyilatkoznia:

Megígérem, hogy a házassági és más női igényeimet, amelyek a férjemmel szemben, akinek vagyonával szemben kincstári követelések is fennállnak, elsőbbségi és különjogokat nem érvényesítek. Azon leszek, hogy hivatalát kötelességtudóan ellássa, és elhanyagolása esetén ne maradjon adósa a kincstárnak. ${ }^{71}$

E formula alapján úgy tủnt, hogy a feleség saját vagyonával is felelt a férje kincstár felé fennálló tartozásaiért. Mindez valószínüleg az érintettek tiltakozását is kiváltotta, és a bányahivatalok nem tudták, hogyan kell alkalmazni a rendeletet, ezért kérdést intéztek az Udvari Kamarához. Az Udvari Kamara a szomolnoki Felügyeleti Föbányahivatalnak címzett dekrétumban pontosította a rendeletét:

A házastárs lemondásáról szóló formulát úgy kell értelmezni, hogy a feleség nyilatkozata semmi esetre sem terjed ki a saját tulajdonában álló vagyonra, csak azokra az igényekre, amelyeket a férje vagyonával szemben házassági szerződés vagy más megegyezések alapján érvényesíthet. ${ }^{72}$

Egy rendelet szerint a feleség nem volt kényszeríthető lemondó nyilatkozat adására, de ha nem adott, férje halála után nem kapott nyugdíjat. ${ }^{73}$ Ebben az esetben a feleségnek érdemes volt mérlegelnie, hogy az elhunyt férje után megillető köve-

\footnotetext{
${ }^{68}$ Az Udvari Kamara rendelete, 1768. március 29. SchmidT: i. m., 13/98.

69 „1222. évi Aranybulla 12. cikkely: Ha valaki meghal, vagy törvény szerint halálra ítéltetett, vagy perdöntő bajon esik el, vagy akármi más ok miá, annak felesége az ő hitbérében kárt ne valljon" (lásd CJH I. 1899, 137). Ezt II. Ulászló 1492-ben megerősítette (lásd 1492:LXIV. tc. CJH I. 523). A feleség követeléseit még a magszakadás miatt az uralkodóra visszaszálló adománybirtokból is ki kellett elégíteni (lásd 1492:LXIII. tc. CJH I. 1899, 522-523).

70 Ld. HoMOKI NAGY Mária: A magyar magánjog története, JATEPress, Szeged, 2005, 33-35.

71 Az Udvari Kamara dekrétuma, 1768. március 29. SchmidT: i. m., 13/98, (fordítás: G. M.).

${ }^{72}$ Az Udvari Kamara dekrétuma, 1769. január 21. SchMIDT: i. m., 13/134, (fordítás: G. M.).

${ }^{73}$ Az Udvari Kamara dekrétuma, 1770. április 20. ScHMIDT: i. m., 13/180.
} 
telései vagy a nyugdíj folyósítása kifizetődőbb-e számára. A Magyar Udvari Kamara 1829-ben kiadott dekrétumából arra lehet következtetni, hogy a feleség nyilatkozatának meglétére a férje után járó nyugdíjjogosultság megállapításakor volt szükség, a feleségnek a nyilatkozatot azonban még a férje életében meg kellett tennie. A reverzális nyújtására a tisztviselöknek nemcsak az első, hanem a további feleségeit is kötelezték. ${ }^{74}$

\subsection{A kaució}

A hivatalra lépő tisztviselőnek megfelelő vagyonnal kellett rendelkeznie, hogy a kauciót le tudja tenni. A vonatkozó rendeletek nem tartalmazták, mekkora volt ez az összeg, egyéb tisztségek viselőinek általában egyhavi fizetésük négyszeresét kellett letenniük. Egy kimutatás szerint a hivatali kaució a pénztárnokok esetében 1250, bányabíró esetében pedig 500 gulden volt. ${ }^{75}$ Péch Antal szerint azonban az 1601ben Selmecbányára kinevezett pénztárnok, Vischer Erasmus, 4000 forintot tett le. ${ }^{76}$

Mivel a kauciót a hivatalba lépéskor kellett letenni, a magasabb hivatalok elérése lehetetlenné vált a kevés pénzzel rendelkező személyek számára. A kauciót készpénzben, ingatlanra feljegyzett zálogjogként, adósságlevél, kezességvállalás formájában, készpénz és zálogjog összekapcsolásával lehetett szolgáltatni. A szerényebb anyagi eszközökkel rendelkezők számára esetlegesen hitelezők adták össze a pénzt. A kauciót egyszer kellett letenni, ha a hivatalnok megváltoztatta a helyét, nem kellett azt még egyszer szolgáltatnia. A hivatal elhagyása vagy a hivatalnok halála esetén a kaució neki vagy az örököseinek visszajárt, addig kamatot fizetett utána a kamara. ${ }^{77}$

A reverzálisok és óvadékok nyújtásának módjára vonatkozóan még a 19. században is számos rendeletet találunk. Ezek a szabályok az időközben kiadott pénzügyi szabályokkal hozták összhangba a pénzkezeléssel megbízott tisztviselőkkel szembeni biztosítékokat, a kincstár anyagi helyzetének változásai is nyomon követhetők bennük.

\subsection{Büntetöjogi felelösség}

A Habsburg udvar azonban nemcsak a reverzálisok és óvadékok segítségével kívánta biztosítani a hivatalnokok hüségét. A kincstár szándékos megkárosításától a tisztviselőket szigorú büntetésekkel igyekeztek elrettenteni.

${ }^{74}$ A Magyar Udvari Kamara dekrétuma, 1829. december 16. ScHMIDT: i. m., 25/131.

${ }^{75}$ Lásd Ammerer, Gerhard: Funktionen, Finanzen und Fortschritt. Zur Regionalverwaltung im Spätabsolutismus am Beispiel des Geistlichen Fürstentums Salzburg. Mitteilungen der Gesellschaft für Salzburger Landeskunde, 1986 (126), 341-518, 506.

${ }^{76}$ PÉCH (1887): i. m., 17.

77 Ammerer szerint a 18. század első felében a kaució összege 130 és 150 gulden között mozgott, de hivatalonként jelentős eltérések lehettek (a hivatalnokok kauciójáról szóló táblázatot lásd AMMERER: i. m., 506). A kaució adásának felsorolt módjai a későbbi rendeletekben megtalálhatóak, amelyekben főként a kezesi és az adósságlevél útján történő kaució biztosítását szabályozták. Ezekből a rendeletekből kiderül, hogy a kincstár számára természetesen a legkedvezőbb a készpénzben szolgáltatott kaució volt. 
Az előbbiek szerint az elszámolással tartozó tisztviselők csak akkor kapták meg kinevezésüket, ha reverzálist adtak arról, hogy a büntetőjogi felelősségre vonásukkal kapcsolatos nemesi előjogaikról lemondanak, és a kamarai joghatóság illetékességét elismerik, valamint alávetik magukat az 1753. április 2-án kihirdetett pátensnek. A pátens szerint azok a hivatalnokok, akik a kamarák pénzét vagy a nyugdíjakat elsikkasztották, az összegtől függő büntetésre számíthattak. Ha az elsikkasztott öszszeg a 10 guldent nem haladta meg, a büncselekmény elkövetése először történt, és más súlyosbító körülmény nem forgott fenn, akkor csak elbocsátották a hivatalnokot, és a feljebbvalója magánjogi úton vonhatta felelősségre, azaz meg kellett fizetnie az eltulajdonított pénzt. Ha az összeg 10 és 150 gulden között volt, akkor megszégyenítésként egy színpadra állították a hivatalnokot, majd nehéz közmunkára osztották be. Ha ilyen munkára alkalmatlan volt, börtönbüntetést kapott: 10-30 gulden sikkasztása esetén 1 év börtönbüntetésre, 30-60 gulden esetén 2 évre, 60-100 gulden esetén 4 évre, 100-150 gulden esetén 8 évre ítélték. Emellett örökre eltiltották a hivatalviseléstöl. 150 vagy több gulden elsikkasztása esetén kötéllel vagy karddal végezték ki a hütlen hivatalnokot. A nem befejezett sikkasztás és részben vagy egészben megtérített kár esetén a meg nem térült mérték büntetését kellett alkalmazni. Ha azonban az elérte a 150 guldent, az elkövetőt ki kellett végezni. ${ }^{78}$

Ha a hivatalnokot büntetésből felfüggesztették az állásából, arra az időre nem járt neki fizetés. Az állás fenntartásával azonban a Hofstelle utalhatott neki összegeket, amelyeket a hivatalnoknak fel kellett jegyeznie, ezt a jegyzéket pedig év végén a Hofstellébe kellett küldenie, amely azt az uralkodó elé terjesztette. ${ }^{79}$

1771-ben az Udvari Kamara előírta, hogy Magyarországon és Erdélyben a tisztviselőkkel szemben indított büntetőeljárásokra az 1769-ben kiadott Kriminalordnung szabályait kell alkalmazni. ${ }^{80}$

\section{A hivatalnokok képzése}

A Habsburg udvar korán felismerte, hogy csak akkor lesz elegendő számú olyan hivatalnok, aki az érdekeit szolgálja, ha maga gondoskodik az utánpótlásáról. Ezért külön gondot fordítottak a gyakornokok megfelelő képzésére. A bányahivatalok felállításáról szóló rendeletekben többször kiemelték a gyakornokok foglalkoztatását. Ezekben az esetekben

bizonyos célszerű képzési formáról van szó, amelyben a kiszemelt, alkalmas ifjú (Expectant) a tapasztalt müszaki szakember mellé beosztva a napi munka során sajátít-

\footnotetext{
${ }^{78}$ Az Udvari Kamara dekrétuma, 1776. április 26. ScHMIDT: i. m., 14/63. A Schmidt-féle gyüjtemény a reverzális adását előíró rendelet mellett a pátens szövegét is ismerteti. A pátens Kasseveruntreuungen címen került 1753-ban kiadásra: Supplementum Codicis Austriaci, oder Chronologische Sammlung aller vom 20-ten Oktober 1740, vom Anbeginne der angetretenen glorreichsten Regierung der Allerdurchlaustigst Großmächtigsten Römischen Kaiserinn zu Hungarn und Böheim Königinn, Erzherzogin zu Oesterreich Mar. Theresiae bis letzten Dezember 1758, Fünfter Theil. Trattner, Wien, 1777, 749.

${ }^{79}$ Az Udvari Kamara dekrétuma, 1773. július 2. ScHMIDT: i. m., 13/384.

${ }^{80}$ Az Udvari Kamara dekrétuma, 1771. március 2. ScHMIDT: i. m., 13/308. Ez a Kriminalordnung a Constitutio Criminalia Theresiana volt.
} 
ja el a szükséges ismereteket. Egy 1676-os rendelet a bányamérést, a kohászatot és a bányamüvelést jelöli meg, mint megismerendő főszakterületet. ${ }^{81}$

A gyakorlati képzés támogatását az Udvari Kamara úgy is elő kívánta mozdítani, hogy a bányahivataloknál fizetett helyeket biztosított a gyakornokoknak. Így például 1761-ben a Selmecbányán végzett gyakornokok pótlására 11, Körmöcre négy, Besztercebányára három gyakornokot lehetett felvenni. ${ }^{82}$ Szomolnokon öt gyakornoknak biztosítottak helyet, akiknek félévente vizsgát kellett tenniük. ${ }^{83} \mathrm{~A}$ nagybányai inspektori hivatalban a képzett hivatalnokok pótlása céljából két gyakornoknak biztosítottak fizetést. ${ }^{84} \mathrm{~A}$ föbányahivatalokba kiküldött rendeletekből látszik, hogy a bányakerületek méretének megfelelően osztották szét a gyakornoki helyeket. A végzett gyakornokok alkalmazását is nyomon kívánta követni az Udvari Kamara, ezért előírta, hogy jelenteni kell, hol, mire alkalmazzák őket, és milyen előmenetelt biztosítanak a számukra. Mivel a zúzóművekben és a kohóknál kevés szakember volt, a Kamara arra is felhívta a fökamaragróf figyelmét, hogy ügyeljen arra, hogy ezeken a helyeken mindig legyen legalább egy gyakornok ${ }^{85} \mathrm{Az}$ Udvari Kamara a gyakornokoknak a házasságkötést is megtiltotta. ${ }^{86}$ Ezt valószínüleg azért tette, mert a gyermekeknek külön ellátást kellett volna biztosítani apjuk halálakor. Az is elöfordult, hogy az Udvari Kamara azzal a kéréssel fordult a fökamaragrófhoz, hogy az ismeretségi körében kutasson megfelelő személyek után, akik a tisztviselői teendőket ellátnák. ${ }^{87}$

A 18. században bányatisztképző iskolák felállításával próbálták a hivatalnokok megfelelő képzettségét elérni. A Selmecbányán meginduló oktatásról, és annak állandó továbbfejlesztéséről a Zsámboki László szerkesztésében megjelent Selmectől Miskolcig (1735-1985) címü kötetben részletes beszámolót olvashatunk. A münek igen értékes része az, amely az iskolákkal kapcsolatos rendeleteket teljes terjedelmükben, magyarra fordítva tartalmazza. ${ }^{88} \mathrm{Az}$ 1735-ben Selmecbányán alapított Bergschuhle számára kiadott instrukció szerint az ott tanulóknak a bányajogban és a bányahivatali eljárásban kellett jártasságot szerezniük, hogy a vitás ügyeket is el tudják intézni. Ezenkívül alapvetőnek tartották a bányamérnöki, bányamérési ismeretek elsajátítását, valamint az ércelőkészítés, a kémlészet és a kohászat technikájának megismerését. ${ }^{89}$

81 ZsÁмвокı László: A földtan oktatásának kezdete (A földtan oktatása a selmeci bányászati-kohászati iskolában). In: Zsámboki László (szerk.): Selmeci ezüst, körmöci arany. Érc- és Ásványbányászati Múzeum, Rudabánya-Miskolc, 2005, 215-234, 218-219. Lásd instrukció, 1676. szeptember 22. ScHMIDT: i. m., 6/237.

${ }^{2}$ Az Udvari Kamara dekrétuma, 1761. szeptember 19. ScHMIDT: i. m., 11/472.

${ }^{83}$ Az Udvari Kamara dekrétuma, 1761. szeptember 19. ScHMIDT: i. m., 11/474.

${ }^{84}$ Az Udvari Kamara dekrétuma, 1761. szeptember 19. ScHMIDT: i. m., 11/475.

${ }^{85}$ Az Udvari Kamara dekrétuma, 1779. augusztus 20. ScHMIDT: i. m., 14/284.

${ }^{86}$ Péch Antal közlése szerint a fökamaragróf 1739. február 1-jén megemlítette, hogy egy Klein nevű írnok házasságot kívánt kötni az özvegy Stegernével. Mivel azonban az expectansok általában az írnokok közül kerültek ki, ezért az írnokok sem köthettek házasságot. Ezért értesítették Kleint, hogy ha házasságot köt, az ő fizetését és az özvegy ellátását is megszüntetik büntetésből. Lásd PÉCH (1967): i. m., 189.

${ }^{87}$ Az Udvari Kamara rendelete, 1724. december 20. ScHмIDT: i. m., 6/230.

88 ZsÁmBOKı László (szerk.): Selmectől Miskolcig (1735-1985), NME, Miskolc, 1985.

89 Instrukció, 1735. június 22. SCHMIDT: i. m., 6/476. Az instrukció fordítását lásd ZsÁmBOKı László: 275 éve kezdődött Selmecbányán a bányászati-kohászati felsőoktatás. Bányászati és Kohászati Lapok, 2010/4, 27-33. 
Mihalovits János 1931-ben megjelent müvében ${ }^{90}$ a Schmidt-féle jogszabálygyűjteményben található rendeletek bemutatásával foglalja össze, milyen iskolákat állítottak fel, és azokban milyen tanrend szerint folyt a tanítás. Az 1735-ben Selmecbányán felállított bányászati iskola mellett ugyanis más tanintézetek is létesültek. 1747-ben Szomolnokon és Oravicán is alapítottak a bányatisztek képzésére szolgáló iskolákat. Ezekben a tanintézetekben közös volt, hogy a bányakerület föbányahivatala alá tartoztak, és nagy súlyt helyeztek a gyakorlati képzésre. Az ott tanulóknak mind a hivatalokban, mind a bányák bejárása során részt kellett venniük a munkában.

A 18. század közepén azonban a bányászattal és kohászattal kapcsolatos természettudományok olyan rohamos fejlődésnek indultak, amellyel az eddigi képzési formák és a gyakornoki rendszer nem tudtak lépést tartani. Ezért 1762. október 22-én Mária Terézia aláírta az Udvari Kamara kibővített bizottságának jegyzőkönyvét, amely „új típusú bányászati-kohászati tanintézet Selmecbányán történő felállításáról rendelkezett”. Ez volt az Academia Montanistica, k.k. Bergakademie, amely a Főkamaragrófi Hivatal keretein belül müködött. Igazgatója a főkamaragróf volt, professzorai egyben a kamara tanácsosaiként is eljártak. Az akadémia megalakulásától kezdve a bányászati-kohászati ismeretek, és a hozzá kapcsolódó természettudományok Európa-szerte híres mühelye volt. ${ }^{91} 1770$-ben, az akadémia teljes felállításakor a selmeci, szomolnoki és bánsági iskolák megszűntek. ${ }^{92} \mathrm{Az}$ addig két évfolyamból álló akadémia 1770-ben három évfolyamra bővült. Az átalakításról szóló rendeletben meghatározták, hogy elsősorban azokat veszik fel, akik gyakornokok voltak, vagy a családjuk kötődött a bányaműveléshez, és valamilyen egyetemi szintű filozófiai képzésben már részesültek. Ha nem volt előképzettségük, a jelentkezőknek felvételi vizsgát kellett tenniük. ${ }^{93}$

A tervezet meghatározta az egyes években tanulandó, teoretikus és gyakorlati tárgyakat, így abban a mai duális képzés előképét fedezhetjük fel. Az első évben a matematika tanulását írták elő, amelyhez gyakorlati tudnivalóként a földmérés, a rajz társult, emellett kéthetenként a tanulóknak ki kellett menniük a bányákba. A második évben az ásványtan és a kohászat volt a tananyag. A gyakorlati részben a professzoroknak az ásványgyüjtemények segítségével kellett megismertetniük a gyakornokokat a különféle kőzetekkel és ásványokkal, a kohászat elsajátításához pedig a kohászati üzemekben való tartózkodást írták elő. A harmadik évben a tulajdonképpeni bányamüveléstanra oktatták a hallgatókat, akik a gyakorlati részt ennélfogva a bányákban töltötték. Mária Terézia azzal írta alá ezt a tervezetet, hogy az erdészet tanítására is gondot kell fordítani az akadémián.

\footnotetext{
A selmecbányai Bergschuhle és a kincstár egyéb megoldásait a szükséges bányatisztek pótlására lásd bővebben: MıHALovits János: Az első bányatisztképző iskola alapítása Magyarországon. M. kir. József nádor Műszaki és Gazdaságtudományi Egyetem Bánya-, Kohó- és Erdőmérnöki Karának Könyvkiadó Alapja, Sopron, 1938.

90 Mihalovits (1931): i. m.

91 ZsÁmвокı László: A Miskolci Egyetem történeti fejlődésének vázlata. In: Zsámboki László (szerk.): Selmeci ezüst, körmöci arany. Érc- és Ásványbányászati Múzeum, Rudabánya-Miskolc, 2005, 169-184, 170.

92 Minalovits (1931): i. m., 23.

${ }^{93}$ Az Udvari Kamara dekrétuma, 1770. április 3. ScHмıDT: i. m., 13/156. A rendelet teljes szövegét magyarul közli ZsÁmBOKI (1985): i. m., 69-85.
} 
Az 1777-ben kiadott Ratio Educationis is tartalmazott a bányászati oktatással kapcsolatos előírásokat. A 145. szakasz elrendelte, hogy - mivel a selmecbányai akadémián az oktatás németül folyt - a központi tanügyi pénzalap terhére alkalmazzanak tanárt, aki a németül nem tudó diákok részére latinul vagy más általuk értett nyelven a bányászattal kapcsolatos tudományokat közvetíti, hiszen nem minden, a bányászati területen haszonnal alkalmazható ifjú tud németül. A rendelet értelmében „senki sem bocsátható e tudományok tanulására, ha előtte megfelelöképpen nem sajátította el az algebra, geometria, fizika, mechanika, és - amennyire lehetséges az ásványtan elemeit”. A Ratio Educationis azt is elrendelte, hogy a szorgalmas diákoknak a „bányászati kamarai kincstár” biztosítson ösztöndíjat. ${ }^{94}$

A tisztviselőkkel szemben támasztott szigorú követelmények mellett tehát az uralkodó és a kincstár azon fáradozott, hogy a hivatalnokok a munkájukhoz szükséges szakértelmet megfelelő módon elsajátíthassák.

\section{A tisztviselők javadalmazása}

\subsection{Fizetés}

A tisztviselők fizetésére vonatkozóan számos információt találhatunk a hivatalokra vonatkozó rendeletekben, hiszen azokban az ott müködő tisztviselőknek járó juttatásokat is szabályozták.

A Schmidt-féle jogszabálygyűjteményben egy egész kötetet tesz ki az alsó-magyarországi, a selmeci, körmöci és besztercebányai hivatalokra vonatkozó, 1751-ben hozott rendelet. Ebben szerepel egy táblázat, amelyben az összes tisztviselőt és a nekik járó juttatásokat is felsorolják. Ebből megtudhatjuk, hogy a hivatalnokok az éves fizetésük mellé természetbeni juttatásokat is kaptak. A főkamaragróf a királyi leirat szerint 12000 gulden évi fizetést kapott. Ebböl 6000 gulden a bányakerületben való utazásainak a finanszírozására szolgált, amelyekre nem kérhetett további összegeket. A főkamaragrófnak a rendelet értelmében évente legalább egyszer el kellett Körmöcbányára vagy Besztercebányára utaznia. Természetbeni juttatásként a főkamaragróf kapott 240 mérő gabonát, 20 szekér szénát, 2 mázsa tiszta faggyút, szükség szerinti tűzifát, két besztercebányai kamarai kert használatát, regáliákat a besztercebányai kamarai falvak és halastavak után. A főbányagondnoknak Szélaknán, a kamarai házban lakhatást is biztosítottak. ${ }^{95}$ A rendeletet 1765 -ben módosították. Az ekkor kiadott táblázatban összehasonlító adatokat is találunk az 1751-ben fennálló helyzethez képest bekövetkezett változásokról. ${ }^{96}$

Ebből a szempontból a Temesi bánságban működő hivatalok személyzetéről készített összefoglalás is igen érdekes, amelyből nemcsak a tisztviselők fizetése derül ki, hanem az is, hogy a szorgalmas, tapasztalt munkaerőt még idősebb korában is

94 Ratio Educationis: Az 1777-i és az 1806-i kiadás magyar nyelvű fordítása / ford., jegyzetekkel és mutatókkal ellátta Mészáros István. Akadémiai Kiadó, Budapest, 1981, 289.

${ }^{95}$ Királyi leirat, 1751. február 12. SchmidT: i. m., 9/9.

${ }^{96} \mathrm{Az}$ Udvari Kamara dekrétuma, 1765. szeptember 17. ScHMIDT: i. m., 12/107. 
nagy becsben tartották, amit anyagilag is kifejezésre juttattak. Így a dognácskai bányászati hivatal élén álló bányamesterről, Ferdinand Onichról a következőket olvashatjuk:

E személy ellen soha vádat nem emeltek, se valamilyen más eljárást nem indítottak. Bányászati tudásában azonban szilárd, fiatalon mint vájár, ezekben a bányákban szerzett tapasztalatot, tisztségéhez tehát bőségesen volt alkalma a tudást megszerezni. Most azonban már idősebb kort ért el, ezért beteges, főként a lába, ennél fogva a bányák bejárásában nem tud részt venni. Pártoskodásba nem bocsátkozott, ezért dicséret illeti.

A bányamester, bár munkabírásában akadályozott volt, 800 forint éves fizetésben részesült. A személyi állományról szóló listában több hasonló leírást olvashatunk. Az elöbbiek ellenkezőjére is találunk példát, amelyben a tisztviselő nem kellő szorgalmát emelik ki. A rendelet szerint több tisztviselőnek ingyenes lakhatást biztosítottak, ezen kívül természetbeni juttatásokat, így szénát, fát és gabonát is kaphattak. Egyes gyakornokoknak a tanulmányait is finanszírozták. ${ }^{97}$

Ha egy tisztviselő új állásba került, a fizetése megállapításánál figyelembe kellett venni, hogy az előző helyén mennyit keresett, ahhoz képest mennyivel nőtt a terhelése, és az új helyén magasabb besorolást ért-e el. ${ }^{98} \mathrm{~A}$ hivatalnokot jó munkájáért ugyanis elöléptethették. Így a fent említett, 1765-ben kiadott rendeletben azt olvashatjuk, hogy a selmeci bánya- és erdőmestert, Anton Körmendit, 29 év hủ szolgálat után bányatanácsossá, fökamaragrófi ülnökké és második fő gazdasági és erdőfelügyelővé nevezték ki. Ezért az új munkakörében 1200 forint fizetést, 300 forint utazási költségtérítést, 36 köbméter fát, 160 mérő szemestakarmányt, 8 szekér szénát és 2 mázsa faggyút kapott.

Bár a jó munkát és hú szolgálatot az udvar igyekezett anyagilag is honorálni, egy 1769-ben kiadott rendelet szerint a távollévő tisztviselőket helyettesítő hivatalnokok nem kaphattak ezért a tevékenységükért külön juttatásokat. Ha egy tisztviselő meghalt vagy egyéb módon megüresedett a helye, amíg az állást be nem töltötték, az őt helyettesítő alacsonyabb rangú hivatalnok nem kaphatta a magasabb bért. Ha azonban a helyettesített tisztviselői állás nagy felelősséggel járt, a tevékenységet ellátó személy a magasabb fizetés $10 \%$-át megkaphatta. Ha a helyettesnek nem járt fizetés, a helyettesített hivatalnok bérének $60 \%$-át, ha a helyettes fizetése a magasabb tisztviselő fizetésének a felét tette ki, a magasabb bér 30\%-át kapta. Ha azonban a helyettesítő hivatalnok végül megkapta az állást, amelyet átmenetileg betöltött, és különleges körülmények nem forogtak fenn, nem kapott külön díjazást. Ha másik helyen kellett valakinek helyettesíteni, mint ahol szolgált, az ezzel járó költségeket megtérítették számára. ${ }^{99}$

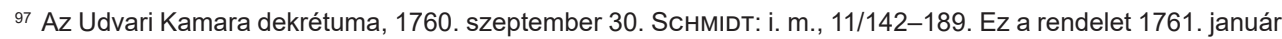
1-én lépett hatályba (ford.: G. M.).

${ }^{98}$ Az Udvari Kamara dekrétuma, 1773. július 30. SchмıDT: i. m., 13/385.

${ }^{99}$ Az Udvari Kamara dekrétuma, 1769. szeptember 2. ScHMIDT: i. m., 13/146.
} 


\subsection{Nyugdij}

Amint arról a reverzálisok aláírásánál már szó volt, a tisztviselö, halála után pedig annak házastársa nyugellátásban részesült. A Schmidt-féle gyüjteményben a tisztviselők nyugdíjára vonatkozóan alig találunk adatot. Míg a bányaművekben dolgozó munkások esetében a fizetéshez hasonlóan a nyugdíjakat is összegszerüen meghatározták, a hivatalnokokkal kapcsolatban csak az elhunytak özvegyeinek és gyermekeinek járó juttatásokra találunk rendeleteket, a hivatalnokok nyugdíjára vonatkozóan csak elvétve találunk utalásokat. ${ }^{100}$ Így a selmeci, körmöci, besztercebányai bányahivatal személyzeti állományáról kiadott rendelet végén csak összesítést találunk arról, hogy a hivatalokban milyen összeget költöttek nyugdijjak kifizetésére. A kiadások csökkentése miatt az Udvari Kamara azt is elrendelte, hogy a bányahatóságok készítsenek arról kimutatást, mely nyugdíjasok alkalmazásával lehetne megoldani egyes állások betöltését. ${ }^{101}$

A nyugellátásokra vonatkozó rendeletekben a Pension és a Provision terminusokat találjuk. Míg a Pension a tisztviselök és özvegyeik nyugellátásának jelölésére, a Provision az üzemekben dolgozó munkások ellátásának jelölésére szolgált. Pensionra jogosultak voltak azok a tisztviselők, akiket a helyükre kineveztek, esküt tettek és legalább 200 gulden éves fizetéssel ellátott posztot töltöttek be. Provisiont azok kaptak, akiknek a feladatuk ellátásához inkább testi erejükre, és nem szellemi tevékenységre volt szükség. ${ }^{102}$

A nagybányai felügyeleti hivatal alá tartozó üzemekben betöltött munkahelyekre vonatkozó táblázat csak a közvetlenül a dolgozókkal érintkező tisztviselőt megillető Provisionról közöl adatokat. A táblázatban szerepel, hogy maga a volt dolgozó mennyi nyugdíjat kapott hetenként, halála után pedig az özvegye mekkora összegủ nyugdíjban részesült. Így a bányafelügyelő hetenként egy forint 30 krajcár nyugdíjat kapott, az özvegye egy forintot. A rendelet azt is megjegyzi, hogy a férfiak csak akkor kaphattak nyugdíjat, ha nyolc éven keresztül feladatukat megfelelően látták el. Ha azonban az özvegy még fiatal volt, aki eltarthatta magát, az elhunyt férjének járó juttatás egy éves összegének felével nyert kielégítést. A gyermekeknek, akiknek se anyjuk, se apjuk nem volt, az özvegyi nyugdíj járt. ${ }^{103}$

1749-ben a királynő a kincstár kiadásainak csökkentése érdekében elrendelte, hogy a titkárok özvegyeinek és árváinak nem jár nyugdíj (Pension). Ehelyett az elhunyt alkalmazott egyéves fizetését, és az arra a hónapra járó havi bért kapták a hátramaradottak, amelyikben a haláleset bekövetkezett. Ezt a juttatást is negyedévenként kifizetve, részletekben kapta meg az özvegy. ${ }^{104}$

100 I. Lipót 1675-ben kiadott leiratában, amelyben a selmecbányai bányabíróság összetételéről rendelkezett, előirta, hogy a bányabírósági írnok, Johann Zweig, élete végéig kapjon hetente egy gulden dénárt. A helyére lépő fia keresete pedig egy gulden 80 dénár legyen (lásd királyi leirat, 1675. július 15. SCHMIDT: i. m., 5/234). Az uralkodó e rendelkezése azonban csak egyedi juttatás volt.

101 Az Udvari Kamara dekrétuma, 1762. szeptember 30. ScHMIDT: i. m., 11/499.

102 KUBISKA, Irene: „Zwischen Anspruch und Gnade” - der Altersversorgung Wiener Hofbedinsteter und ihrer Witwen und Waisen im 18. Jahrhundert. In: István Fazekas (et all. Hrg.): Frühneuzeitforschung in der Habsburgermonarchie, Adel und Wiener Hof - Konfessionalisierung - Siebenbürgen. Institut für Ungarische Geschichtsforschung, Wien, 2013, 33-50, 42, 43.

${ }^{103}$ Az Udvari Kamara rendelete, 1766. január 27. ScHMIDT: i. m., 12/411.

104 Királyi leirat, 1749. július 2. SchmidT: i. m., 8/58. 
1762-ben az Udvari Kamara előírta, hogy át kell vizsgálni a nyugdíjak mértékét, és jelentést kell róluk készíteni. A bányamunkások mellett a tisztviselők özvegyeinek és gyerekeinek járó nyugdíjaknál is bevezették azt az elvet, hogy a természetes halállal eltávozottak hátramaradottjai a tisztviselő éves fizetésével nyerjenek kielégítést, a szolgálatteljesítés közben szerencsétlenül jártak fizetésének a harmadát kapják ellátásként a hozzátartozók. A 12 év feletti árváknak már nem járt nyugdíj. ${ }^{105}$

A nyugdíj megállapításánál pedig azt is figyelembe kellett venni, hogy az özvegynek vagy az árvának volt-e saját vagy örökölt vagyona. ${ }^{106} \mathrm{Az}$ az özvegy, akinek nem volt gyermeke, csak akkor kapott nyugdíjat, ha legalább négy éve volt házas. Ellenkező esetben csak végkielégítést kapott. ${ }^{107} \mathrm{Az}$ árváknak járó nyugdíjaknál a gyermekek életkorát külön-külön kellett vizsgálni. ${ }^{108}$ Az Udvari Kamara az évenkénti felülvizsgálatát rendelte el annak, hogy az árváknak a koruknál fogva, vagy egyéb vagyonosodás miatt jogosan jár-e még a nyugdíj. ${ }^{109}$

1771-ben az Udvari Kamara egységes szabályokat állapított meg a tisztviselők özvegyeinek és gyermekeinek folyósított ellátással (Pension) kapcsolatban. A rendelet szerint a gyermekes özvegyeknek az elhunyt férj fizetésének a harmada járt. Az özvegy halálával a gyermekek az elhunyt apjuk fizetésének a felét kapták. Ha a gyermekek elérték a serdültséget, vagy meghaltak, az özvegynek akkor is járt az egész ellátás. A gyermekek azonban, ha elérték a serdültséget, vagy adomány, örökség folytán megváltozott az anyagi helyzetük, nem kapták tovább az ellátást. Ha azonban az özvegy és a gyermek nem rászorultsági alapon, hanem az elhunyt tisztviselő kimagasló munkája miatt kapta az ellátást, azt halálukig folyósították számukra. ${ }^{110}$ Az özvegyeknek és gyermekeknek akkor is járt a nyugdíj, ha az elhunyt tisztviselő jubilált fizetést kapott. ${ }^{111}$ Később azonban ehhez a rendelethez azt a magyarázatot füzték, hogy az özvegyeknek és gyermekeknek járó juttatást nem a jubilált, hanem az azt megelőző fizetés alapján kell meghatározni. ${ }^{112} \mathrm{~A}$ „Jubilation” azokat a tisztviselőket illette, akik 40, 55 év hü szolgálat után, tényleges munkavégzés nélkül továbbra is megkapták a teljes fizetésüket. ${ }^{113} \mathrm{Az} 1749$-ben kiadott, a nagybányai főbányahatóság személyzetéről szóló rendeletben például azt az adatot találjuk, hogy a föbányaintéző 300 forint nyugdíjat (Pensiont) kap. ${ }^{114}$ A rendelkezés megszövegezéséből - a tisztviselő kegy alapján, és továbbra is kapja ezt a pénzt - arra lehet következtetni, hogy egy Jubilationról volt szó.

II. József vezette be a tisztviselők számára az egységesített nyugdíjrendszert. A fizetése harmadát kapta nyugdíjként az, aki tíz éve tisztviselő volt. 25 év után a fizetés fele, 40 után az egész fizetés járt. ${ }^{115}$

\footnotetext{
${ }^{105}$ Az Udvari Kamara dekrétuma, 1762. március 9. ScHMIDT: i. m., 11/481.

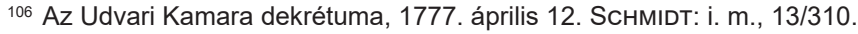

107 Az Udvari Kamara dekrétuma, 1778. október 9. SCHMIDT: i. m., 14/251.

${ }^{108}$ Az Udvari Kamara dekrétuma, 1764. május 1. ScHMIDT: i. m., 12/6.

${ }^{109}$ Az Udvari Kamara dekrétuma, 1765. november 25. ScHMIDT: i. m., 12/409.

${ }^{110}$ Az Udvari Kamara dekrétuma, 1771. január 11. SCHMIDT: i. m., 13/299.

111 Az Udvari Kamara dekrétuma. 1771. március 1. SCHMIDT: i. m., $13 / 307$.

112 Az Udvari Kamara dekrétuma, 1771. szeptember 28. ScHMIDT: i. m., 13/344.

113 KUBISKA: i. m., 42.

114 Királyi leirat, 1749. július 23. SchMidT: i. m., 8/67.

115 SporschIL, Johann: Neueste Geschichte der Österreichischen Monarchie I. Friedrich Volkmar, Leipzig, $1845,461$.
} 


\subsection{Egyéb juttatások}

Az elhunyt tisztviselő után özvegye és gyermekei a nyugdíjon kívül további juttatásokban részesülhettek. Ilyen juttatás volt a temetési támogatás vagy kegydijj. ${ }^{116}$ A temetési támogatás azonban nem járt automatikusan, azt csak méltányosságból lehetett megítélni. ${ }^{117}$ Egy rendeletben elöírták, hogy az elhunyt tisztviselő özvegyének vagy gyermekének járó temetési vagy kegydíj kiszámításánál csak a hivatalnok fizetését kell figyelembe venni, tehát a természetben járó juttatásokat nem. ${ }^{118}$ Bár az uralkodó korábban eltörölte a temetési támogatást, ha a hivatalnok olyan szegény volt, hogy nem lehetett számára tisztességes temetést biztosítani, a temetési segély érdekében a hivatalhoz kellett kérelmet benyújtani, amelynek teljesítését az Udvari Kamara támogatta. ${ }^{119} \mathrm{Az}$ Udvari Kamara már korábban is arra az álláspontra helyezkedett, hogy a segélyre való jogosultságot mindig egyénileg kell elbírálni. ${ }^{120}$

Az egészségkárosodásnak kitett kohászati tisztviselőknek a felsőbányai ólombányászatban a gyógyszerköltséget a kincstár megtérítette, ha azt az orvos javasolta. Ezt a kedvezményt azonban nem terjesztették ki a tisztviselő feleségére és gyermekeire. ${ }^{121}$

A tisztviselöknek a kamara lakhatást is biztosíthatott. Az épületek karbantartására és a takarítására költendő összegeket is a kamara nyújtotta. Így a kamara fizette azokat a kiadásokat, amelyek az idő múlásával következtek be, mint a régi, használhatatlan kályhák, szobák, padlók, ajtók, zárak, ablakkeretek kicserélését, illetve felújitását, viharkárok vagy egyéb véletlen sérülések kijavítását. A kamara fizette a házakhoz járuló költségeket, így az adókat, világítást, kéményseprőt, házmestert, takarítókat, a kutak karbantartását. A lakóknak kellett azonban gondoskodni a szobákban lévő berendezések fenntartásáról és tisztításáról, mindarról, ami nem volt szükségszerü, és ami csak a kényelmüket szolgálta. A lakóknak kellett kimeszelniük a szobákat, a tanácstermet és a könyvelöirodát azonban a kincstár költségére festették ki. Az ajtók és ablakok saját igény szerint történő átalakítását saját költségre lehetett elvégezni, ehhez azonban a hivatal egyetértését is be kellett szerezni. ${ }^{122}$

\footnotetext{
${ }^{116}$ Péch Antal által összegyüjtött selmeci bányaigazgatósági adatokból például arról értesülhetünk, hogy 1688. október 6-án Dedda János kohóírnok özvegyének 500 forint kegydíjat engedélyeztek. Lásd PÉCH (1967): i. m., 83.

117 Az Udvari Kamara dekrétuma, 1730. május 12. Schmidt: i. m., 6/408. A rendeletből kiderül, hogy egy gyakornok özvegye szeretett volna temetési támogatást kapni, ami 21 gulden volt.

118 A Pénzverési- és Bányaigazgatási Udvari Kollégium dekrétuma, 1755. június 7. ScHMIDT: i. m., 10/257.

119 Mária Terézia rendelete, 1773. december 4. ScHMIDT: i. m., 13/397.

120 Az Udvari Kamara dekrétuma, 1764. augusztus 14. ScHMIDT: i. m., 12/15.

121 Az Udvari Kamara dekrétuma, 1780. február 4. ScHMIDT: i. m., 14/325.

${ }^{122}$ Az Udvari Kamara dekrétuma, 1780. február 18. SCHMIDT: i. m., 14/326.
} 


\section{6. Összegzés}

A Habsburg udvar elérte, hogy az országban a bányaigazgatás területén kiépüljön egy hierarchikusan felépített, a magyar szervektöl elkülönülö, zárt szervezet. Ennek élén az uralkodó állt, akinek minden rendelkezése a vájárok szintjén is kifejtette hatását. A bányaigazgatás zárt rendszerének kiépítésével való esetleges szembenállást általában a szakértelemre való hivatkozással hárították el. Eljárásukat megkönnyítette az a körülmény, hogy a bányászattal és kohászattal kapcsolatos szakkifejezések német nyelven terjedtek el, hiszen kezdetben a bányászati tevékenységet a hazánkba telepített német hospesek végezték, akik német nyelven megfogalmazott jogkönyveiket is magukkal hozták.

Ennek megfelelöen a hivatalokban is a német volt a szaknyelv, a rendeleteket is németül fogalmazták, az idegen tisztviselőknek nem kellett nyelvi nehézségekkel küzdeniük. A minél több bevétel érdekében kiadott rendeletek megfogalmazásán az a kétségbeesés is érződik, amellyel az udvar a hadsereg finanszírozásához szükséges pénzt minél gyorsabban próbálta megszerezni. A szakértelem valódi megteremtésének érdekében a Habsburg udvar a hivatalnokok és munkások képzésére is gondot fordított, erőfeszítéseiket, ha csekély mértékben is, különféle kedvezményekkel honorálta.

A Habsburgok a bányaigazgatás központosításával és a hozzájuk hủ bürokrácia kiépítésével elérték, hogy a bányakincsekkel egyedül ők rendelkeztek. Így a bányaregáléból eredő jövedelem nem a Szent Koronát, hanem a nyugati típusú hübériség alapján a király személyét illette meg. Bár II. József idején a magyar bíróságok némi befolyást szereztek a bányabíráskodás felsőbb fórumain, az Udvari Kamara mesterkedése megakadályozta, hogy a hazai befolyás az alsóbb szinteken növekedni tudjon. A rendek II. József halála után törvényhozás útján igyekeztek befolyásukat visszaszerezni ezen a területen, azonban az 1844-ben született törvényjavaslatot - mely ezt lehetővé tette volna - az uralkodó nem szentesítette.

A fordulat 1867-ben következett be, amikor Ferenc József elrendelte a magyar minisztériumok visszaállítását. Az uralkodó akaratát megtestesítő főkamaragrófot 1867-ben már a magyar nemesek közül választották, és levelezésében a magyar nyelv használatát követelték meg. ${ }^{123} \mathrm{~A}$ források azt is megfelelöen tükrözik, hogy a bányaregálé kisajátítását a Habsburg uralkodók részéről a magyar hivatalnokok sem nézték jó szemmel. A változásoktól valószínűleg azt várták, hogy Magyarország is profitálhat a bányászati tevékenységből.

A Habsburg udvar bányahivatalnokokra vonatkozó szabályozásának bemutatása egyrészt az abszolutizmussal kapcsolatos ismereteinket gyakorlati szempontból gyarapítja. Másrészt a mai viszonyokra vonatkozóan is találhatunk benne néhány párhuzamot és megfontolandó megoldást. A Mária Terézia uralkodása alatt a szakemberek pótlására tett erőfeszítésekben, a kétkezi munkások szintjéről induló és a

123 PORKOLÁв László: Források Diósgyőr-Vasgyár történetéhez 1770-1919. (Tanulmányok Diósgyőr történetéhez, 12.). Borsod-Abaúj-Zemplén Megyei Levéltár - Országos Műszaki Múzeum Központi Kohászati Múzeuma, Miskolc, 2003, 27. 
legelőkelőbb hivatalnokok rangjára jutó személyek támogatásában a mai életpályamodelleket és a duális képzés előképeit fedezhetjük fel.

Ma is megfontolandó lenne a felelösségi köröknek az újkorban szokásos, pontos meghatározása, hiszen azzal a hatékonyságot és az ügyek megfelelő elintézését jobban elő lehetne segíteni. Az azonban már a 18. században is világossá vált, hogy mindehhez a hivatalnokok megfelelő javadalmazása, és munkaképtelenségük esetén is megfelelő ellátása nélkülözhetetlen volt. Mindez napjainkban az egyre jelentősebbé váló emberierőforrás-eszközökre épülő személyzeti politikában, és a piaci viszonyokhoz igazodó munkajogi foglalkoztatási formák folyamatos megjelenésében is tetten érhető. A múltunk tapasztalatai segítenek minket az előttünk álló kihívásoknak való megfelelésben. 